Salsola sp. A of Flora Zambesiaca from the coast of Mozambique is Caroxylon littoralis (Amaranthaceae subfam. Salsoloideae), hitherto only known from Madagascar

Friis, Ib; Holt, Sune

Published in:

Webbia

DOI:

10.1080/00837792.2016.1258788

Publication date:

2017

Document version

Peer reviewed version

Document license:

Unspecified

Citation for published version (APA):

Friis, I., \& Holt, S. (2017). Salsola sp. A of Flora Zambesiaca from the coast of Mozambique is Caroxylon littoralis (Amaranthaceae subfam. Salsoloideae), hitherto only known from Madagascar. Webbia, 72(1), 63-69. https://doi.org/10.1080/00837792.2016.1258788 


\section{Salsola sp. A of Flora Zambesiaca from the coast of Mozambique is Caroxylon littoralis}

(Amaranthaceae subfam. Salsoloideae), hitherto only known from Madagascar

Ib Friis $^{\mathrm{a} 1}$ and Sune Holt ${ }^{\mathrm{b}}$

${ }^{a}$ Biosystematics, Natural History Museum of Denmark, Sølvgade 83, DK-1307 Copenhagen K, Denmark (ibf@snm.ku.dk); ${ }^{b}$ previously Danish Red Cross, c/o Cruz Vermelha de Mozambique, Av. Agostino Neto 284, Maputo, Mozambique; now Asserbo Consulting S.A., Calle Pancho Luz, Ticuantepe, Managua 10270, Nicaragua (suneholt@asserbo.com).

\footnotetext{
${ }^{1}$ Corresponding author. ibf@snm.ku.dk
} 


\begin{abstract}
We have identified plants from the coast of the Inhambane Province, Mozambique, with the incompletely known species Salsola sp. A of Flora Zambesiaca and with Caroxylon littoralis (Moq.) Akhani \& Roalson (Salsola littoralis Moq.), a species hitherto believed to be endemic to Madagascar and Île Europa. We have placed Salsola sp. A in synonymy of C. littoralis, amended the description of the combined taxon and mapped its distribution. There is continuous variation between Salsola littoralis var. littoralis and var. glabra Botsch. and we cannot uphold the infraspecific taxa. Caroxylon littoralis differs from most other species of Caroxylon in being a coastal, perennial species with opposite leaves and deviating anther appendages, and it does not develop a dorsal wing on the fruiting perianth. The fruit is an achene. The taxonomic position of $C$. littoralis should be clarified by the study of DNA sequences in comparison with already known sequences of Old World Salsoleae. We assess the conservation status based on the extended distribution of the species as Least Concern to Near Threatened (LC-NT); the species may be potentially threatened if development of tourism in the coastal zone threatens the limited number of locations.
\end{abstract}

Key words: conservation assessment, coastal habitats, identification, distribution, taxonomy 


\section{Introduction}

One of us (Sune Holt; SH) studied a plant readily identified as Salsola sp. A of Flora Zambesiaca (Brenan 1988) at Vilankulo in the Inhambane Province, Southern Mozambique. This unnamed species was previously not known from this locality, but had in 1958 been collected by A. O. D. Mogg on Ilha Mocucuni, near the town of Inhambane and c. $210 \mathrm{~km}$ south of Vilankulo, and at Cabo di São Sebastião, c. $22 \mathrm{~km}$ south-east of Vilankolo. The field studies at Vilankulo were made from August 2015 to March 2016. Herbarium specimens from the Vilankulo population have, via Mark Hyde, Zimbabwe, been delivered to the National Herbarium and Botanic Garden (SRGH), Harare, Zimbabwe, and to the Buffelskloof Herbarium (BNRH), South Africa. One of us (SH) readily identified the plant with Salsola sp. A of the Flora Zambesiaca. (Brenan 1988). Apart from two already known collections of Salsola sp. A at SRGH, no other matching collection was found at either institution. Later, SH brought material to the herbaria of the Natural History Museum, Copenhagen, Denmark (C), and to the Royal Botanic Gardens, Kew, UK (K), where it was studied by Ib Friis (IF), but again no more matching collection was found. Attempts at identification of the material with a key to the species of Salsola in southern Africa (Botschantzev 1974) suggested that the plant belonged to Salsola sect. Caroxylon (Thunb.) Fenzl subsect. Tetragona (Ulbrich) Botsch. However, unlike most of the species in sect. Caroxylon, our plant did not develop a horizontal wing on the abaxial side of the perianth. Botschantzev (1974) placed species of Salsola without a horizontal wing on the abaxial side of the perianth in a special group of his subsect. Tetragona. This group included his species numbers $61-67$ at the end of the subsection, but our plant did not match any of these species, nor did it match any species of Salsola described later by Botschantzev (1978, 1981, 1983) from southern Africa. We therefore assumed that it might be an undescribed species and focussed on a review of the field observations. 


\section{Field observations at Vilankulo, Mozambique}

Two big and well-developed plants with sturdy roots were studied at Vilankulo, Mozambique. The roots of the plants were anchored firmly in hard coral rocks. The locality was visited on 9 August, 9 September, 6 October, and 13 November, 2015, and again on 24 January, 2016. During low-tide, the plants were exposed to full sunshine (Fig. 1A), while at high tide, the plants were immerged by sea-water and exposed to strong waves and currents for at least an hour during each high tide (Fig 1B). From 6 October, 2015, to the 24 January, 2016, specimens were repeatedly collected and fresh material was scanned and photographed in order to cover as broad a range of the phenological cycle as possible. Habitats similar to those at Vilankulo, with coral rocks exposed at low tide, are scarcer along the coastline of southern Mozambique than in the northern part of the country; the distribution of coral reefs in southern Mozambique (Motta et al. 2000, Fig. 1) agrees with the other known populations of Salsola sp. A, which are mentioned by Brenan (1988): at Inhambane Island and at Cabo di São Sebastião. These populations must be expected to have grown in similar types of environment as our population at Vilankulo.

The variation in tide is high in southern Mozambique, up to $4.5 \mathrm{~m}$. The plants at Vilankulo had up to $150 \mathrm{~cm}$ long, creeping, or, at high tide, floating stems. The older stems were partly woody, but flexible (Fig. 1C, 1D), although most prostrate stems were $50-90 \mathrm{~cm}$ long and up to c. $0.8 \mathrm{~cm}$ thick. The older, prostrate stems were leafless, but with numerous leaf-scars, while the erect, slender, branched and leafy stems carried leafy branches and spikes of flowers. The flowers were supported by bracts hardly different from the normal leaves and each flower surrounded by two bracteoles almost as long as the membranous perianth (Fig. 1F, 1G, 1H). It was observed that flowers with protruding anthers and style were submerged at high tide, and that the bracteoles and perianth lobes closed around the anthers and style as soon as the plant began to dry out after having been submerged, but opened up again when the plant became wet at the next high 
tide. After anthesis, the perianth turned brown and remained smooth; no sign of horizontal dorsal wing or even a dorsal swelling developed. Fruits were very difficult to obtain. In the field SH observed once (October 7, 2015) two ca. $2 \mathrm{~mm}$ long fruits with a hardening shell and a seed developing inside (Fig. 1K). The two fruits turned brown and can be described as achenes. They seem to fall off very easily and were probably washed away by the tidal waves.

High resolution images from the population at Vilankulo are uploaded at the website of the Flora of Mozambique (http://www.mozambiqueflora.com).

\section{Identification of our material and Salsola sp. A with Caroxylon littoralis; taxonomic position}

Having failed to identify our plant from Vilankulo with any other taxon than Salsola sp. A of the Flora Zambesiaca, we realised that the shoreline-habitat of the new species made it relevant for us to look for similar species in other coastal areas around the southern part of the Indian Ocean, rather than in the inland areas of Southern Africa. In Flore de Madagascar (Cavaco 1954), only one species of Salsola, S. littoralis Moq., was recorded, known from the west and south-west coast of Madagascar and from Europa Island (Île Europa), an atoll in the Mozambique Channel between southern Madagascar and southern Mozambique. Salsola littoralis had until now been believed to be endemic to Madagascar. Botschantzev (1969, Fig. 1) referred S. littoralis to his Salsola sect. Caroxylon (Thunb.) Fenzl and mapped it as occurring in a small coastal zone of south-west Madagascar. In a revision of Salsola sect. Caroxylon subsect. Tetragona Botschantzev (1972) gave an amended description of S. littoralis and established two varieties based on the indumentum of the plants var. littoralis and var. glabra Botsch. The two varieties were said to grow together. We compared our material from Vilankulo with the material of Salsola littoralis available in the herbarium of Museum d'Histoire Naturelles, Paris (P; seen on 
https://science.mnhn.fr/institution/mnhn/collection/p/item/search and https://plants.jstor.org/), and we saw the material at De Candolle's Prodromus herbarium (G-DC) cited by Moquin-Tandon (1849) on the microfiche edition of that herbarium (IDC 1962). The material at $\mathrm{P}$ collected before $\mathrm{c}$. 1970 had all been seen and annotated by Botschantzev. The descriptions and images of Salsola littoralis agree well with the description of Salsola sp. A by Brenan (1988) and with our material from Vilankulo. In spite of some variation in the indumentum of young stems and leaves we have concluded that all material from Madagascar, Île Europa and the coast of Mozambique belongs to the same species and that the invalid name Salsola sp. A is therefore a synonym of Salsola littoralis.

Based on analyses of nuclear ribosomal internal transcribed spacer (ITS) and chloroplast $p s b B-p s b H$ DNA sequences, Akhani, Edwards \& Roalson (2007) carried out a phylogenetic analysis and produced a new classification of the old world Salsoleae s.l., which they divided into two monophyletic tribes, Salsoleae s.str. and Caroxyleae ['as 'Caroxyloneae']. Akhani, Edwards \& Roalson (2007, Table 3) distinguished tribus Caroxyleae from tribus Salsoleae by the plants of the former being mostly annual, the stems never articulated, the leaves almost always alternate and always spineless, the stems, leaves and perianths provided with long, white, articulated, multicellular hairs, and also sometimes with medifixed hairs, the anthers in various ways appendiculate, with anther appendages mostly separated from the thecae and of a colour different from that of the anthers, with the perianths mostly with a horizontal wing on the abaxial side (absent in some genera), and by being inland plants with the highest concentration of species in central and southwestern Asia and in northern and southern Africa. Akhani, Edwards \& Roalson also re-established the genus Caroxylon Thunberg, but they did not provide any new circumscription of the genus. Akhani, Edwards \& Roalson transferred Salsola littoralis to Caroxylon, as C. littoralis (Moq.) Akhani \& Roalson, but they published no sequences of nuclear 
ribosomal internal transcribed spacer (ITS) and chloroplast $p s b B-p s b H$ DNA of the species. Caroxylon littoralis did not appear in their cladograms, and no material of the species was cited.

Our observations in the field at Vilankulo and on herbarium material confirm that our plant has indeed long, multicellular hairs on stems and leaves (Fig. 1E, 1G), and in that character it therefore agrees with Akhani, Edwards \& Roalson's description of tribus Caroxyleae, but the specimens we have examined are less hairy than what appears from the descriptions by both Moquin-Tandon (1849) and Cavaco (1954). With regard to the presence of long hairs, our plants are intermediate between Botschantzev's Salsola littoralis var. littoralis and var. glabra. Our plants also differ from typical species of tribe Caroxyleae in being semi-woody perennials or subshrubs, not annuals, in having opposite leaves, in having the saccate anther-appendages as basal swellings of the thecae and the appendages having the same colour as the rest of the anthers. Moreover, our plants develop no horizontal wing and no swellings on the abaxial side of the perianth segments, and its habitat differs from nearly all other species in the tribe in being strictly coastal, in fact always very close to the sea. On the available evidence, we agree that our plants belong to tribus Caroxyleae, but in a wider sense than that of Akhani, Edwards \& Roalson (2007, Table 3). We also find it difficult to confirm that our plant truly belongs to the genus Caroxylon, particularly because Akhani, Edwards \& Roalson did not provide an amended description of that genus. As appears from the review by Botschantzev (1974), our plants differ from most other species of Caroxylon (in the sense of Botschantzev's sect. Caroxylon) in having opposite leaves and in being strictly coastal. It is a complication that mature fruits and seeds of our species are still very scarce, but the taxonomic position of $C$. littoralis can be further studied by using our Vilankulo material for extracting sequences of nuclear ribosomal internal transcribed spacer (ITS) and chloroplast $p s b B$ - $p s b H$ DNA and compare this with the sequences already provided by Akhani, Edwards \& Roalson (2007). 
In the following we have amended the description of $C$. littoralis, summarized the now known data on its distribution and provided a conservation status based on this information and our field observations.

\section{Taxonomy, distribution and conservation status}

Caroxylon littoralis (Moq.) Akhani \& Roalson, Internat. Journ. Plant Sci. 168(6): 947 (2007).

(三) Salsola littoralis Moq., Prodr. 13(2): 180 (1849).

Type: Madagascar, bay at St. Augustin, 1839, Bojer s.n. (G-DC, holo; P [P00799069 \& P00487034], iso).

(=) Salsola littoralis Moq. var. glabra Botsch., Novosti Sistematiki Vyssich Rastenij [Novitates Systematicae Plantarum Vascularium] 9: 162 (1972).

Type: Madagascar, plant with creeping and branching stems, growing together with Arthrocnemum on sand in the saline zone, surroundings of Morondera, no alt., September 1956, J. Bosser 9844 (P [P04168476], holo)

(=) Salsola sp. A., sensu Brenan, Flora Zambesiaca 9(1): 159-161 (1988).

Low, spreading or prostrate subshrub with prominent tap-root (Fig. 1A, 1B); young stems herbaceous, with green bark; older stems woody, with brown bark (Fig. 1D) or brownish-black bark (specimens from Madagascar), 3-4 (-5) mm in diam. Branches opposite (Fig. 1C), when young densely to scarcely pubescent with long, multicellular, white hairs (Fig. 1G), soon becoming 
glabrescent, or almost glabrous from the youngest stage. Leaves opposite, scale-like, succulent, imbricate on young stems (Fig. 1D, 1E, 1F), on older stems with internodes 5 - 8 mm long, ca. 2 -3 x $2.5-3.5 \mathrm{~mm}$, when young with long, white hairs (as on the stems), most prominent on the adaxial side (Fig. 1E), but sometimes glabrous when young, later always glabrescent, margin almost always ciliate (Fig. 1E, 1F), soon becoming subglabrous, with thickened, pale and translucent midrib and translucent margins (Fig. 1D, 1E), apex rounded or obtusely pointed. Flowers solitary in the axils of bracts as long as or slightly shorter, but otherwise hardly different from normal leaves, and surrounded by two lateral bracteoles. Bracts ovate, with thickened, pale and translucent midrib and translucent margins, $1.8-2 \times 1.5-2.0 \mathrm{~mm}$, occasionally with hairs like the leaves, but usually glabrous, becoming spongy after anthesis and (according to Botschantzev 1972) reaching a size of $2.5 \times 2.3 \mathrm{~mm}$. Bracteoles ovoid, with midrib and margins as the bracts, $1.6-1.8 \times$ ca. $1.2 \mathrm{~mm}$, approximately $2 / 3$ of the length of the perianth, swelling and fusing after anthesis (Fig. 1H) and (according to Botschantzev 1972) reaching a size of $2.0-2.5 \times 1.5-1.7 \mathrm{~mm}$. Perianth with 5 green, membranous segments (Fig. 1J), at anthesis $2.5-3.0 \times 0.8-1.4 \mathrm{~mm}$, the three outer ones slightly wider than the two inner ones, without swelling or horizontal wing on the abaxial side. Stamens 5; filaments attached below a hypogynous disk, filiform or slightly flattened, $0.6-0.8$ $\mathrm{mm}$ long; anthers slightly longer than filaments, ca. $1.3 \times 0.4 \mathrm{~mm}$, saccate at the base, narrowing towards the apex, which is prolonged into a ca. $0.1 \mathrm{~mm}$ long, white tip (appendage). Hypogynous disk with 5 short, rounded lobes, one between each filament. Pistil narrowly ovoidal, gradually narrowing into the long style, $3.0-3.5 \mathrm{~mm}$ long; style exerting from the perianth during anthesis (Fig. 1F), divided into two long stigmas. After anthesis the perianth segments become more fibrous and change colour to brown (Fig. 1G). Fruit a ca. $2 \mathrm{~mm}$ long achene with brown shell (Fig. 2K). Seed vertical (according to Botschantzev 1972). 


\section{Collections and Locations}

The collections have been arranged to the collecting localities in nine locations (see further in

'Conservation status'). The decimal degrees in square brackets indicate the approximate position of each location, as we have estimated them from satellite images on Google Earth (2016). Specimens indicated with bar-code numbers from $\mathrm{P}$ have been seen as digital images.

MOZAMBIQUE. Vilankulo \& Cabo de São Sebastião: San Sebastião [22.1006 ${ }^{\circ}$ S, $35.4602^{\circ}$ E], 10 Nov. 1958, Mogg 29153 (LISC; SRGH); on coral rocks, Vilankulo, 21 56.27’ S, 35²19.12’ E [21.9378 ${ }^{\circ}$ S, $35.3187^{\circ}$ E]. 9 Sep. 2015, S. Holt F7855 (SRGH!, BNRH!, K!, C!, LISC!); ibid., 6 Oct. 2015, S. Holt F7952 (K!, C!, , LISC!, P!, FT!); ibid., 13 Nov. 2015, S. Holt F8453 (K!, C!); ibid., 24 Jan. 2016, S. Holt F8868 (K!, C!, LISC!, P!); ibid., 24 March, 2016, S. Holt F8888 (K!, C!, LISC!, P!, FT!).

Inhambane: Ilha Mocucuni [23.8464 ${ }^{\circ}$ S, 35.3914 E], 20 Nov. 1958, Mogg 29302 (LISC; SRGH)

TERRES AUSTRALES ET ANTARCTIQUES FRANÇAISES. Îles Éparses, Île Europa $\left[22.3680^{\circ} \mathrm{S}\right.$, 40.3598 E]: near the sea, June 1921, H. Perrier de la Bâthie 13827 (P [P04618484, P04618485 \& P04618486]); no alt., 10 April, 1948, M.R. Saboureau 1703 (P [P04618469]; Plaine centrale, Sansouire, $22^{\circ} 22^{\prime} 05^{\prime \prime}$ S, 40 21' 35" E, 1 m a.s.1., 5 April 2011, CBNM-IE, Jean Hivert, V. Boullet \& Luc Gigord 42 (CBNM, MO, P).

MADAGASCAR. Morondava $\left[20.3056^{\circ} \mathrm{S}, 44.2571^{\circ} \mathrm{E}\right]$ : plant with branches lying on the sand in the salty zone with Arthrocnemum polystachyum, around Morondava, no alt., September 1956, J. Bosser 1844 (P [P04618491]); plant with creeping an branching stems with Arthrocnemum on sand in the saline zone, surroundings of Morondava, no alt., September 1956, J. Bosser 9844 
(P[P04168476]); sandy areas near Morondava, densely tufted, no alt., September 1925, H. Perrier de la Bâthie 17342(P [P04618488, $\mathrm{P} 04618494, \mathrm{P} 04618481$ \& $\mathrm{P} 04618479]) ;$

Tulear $\left[23.3333^{\circ} \mathrm{S}, 43.6667^{\circ} \mathrm{E}\right]:$ sparsely forested area with limestone rocks, Tulear Province, Tulear, c. 20 m a.s.1., 6 Feb. 1975, T. B. Croat 30862 (MO, P [P04618887]);

St. Augustin $\left[23.6422^{\circ} \mathrm{S}, 43.6512^{\circ} \mathrm{E}\right]$ : at bay of St. Augustin, no date, Bojer s.n. (G-DC; P [P00799069 \& P00487034]); lagoons at the coast south of St. Augustin, no alt., May 1910, $H$. Perrier de la Bâthie 8636 (P [P04618470, P04618487 \& P04618489]);

Lac de Tsimanampestsotsa $\left[24.0715^{\circ} \mathrm{S}, 43.7416^{\circ} \mathrm{E}\right]$ : salty area, Lac Manampestsotsa, no altitude, 23. Oct. 1940, J. Decary 16050 (P [P04618492]); branching plant growing in salty area, Lac Manampestsotsa, no altitude, 24 Oct. 1940, J. Decary 16059 (P [P046188507]); saline places in xerophytic bushland on calcareous dunes and sand, edges of Lac Tsimanampestsotsa, $1 \mathrm{~m}$ a.s.1., 13 - 16 Feb. 1947, H. Humbert 20245 (MO, P [P04618482]); Euphorbia bushland around Lac Tsimanampetsotsa, Ambalohatoy, north-east of Efoetsy [the latter two place names not located], 0100 m a.s.l., 24 Nov. 1960, J. Leandri \& P. Saboreau 4025 (P [P04618480]); shore of saline lake, Lac Tsimanampestsotsa, no alt. [c. 1 m a.s.1.], March 1962, J. M. Bosser \& G. Viennot-Bourgin 15432 (P [P04618508]);

La Linta $\left[25.0352^{\circ} \mathrm{S}, 44.0695^{\circ} \mathrm{E}\right]$ : sandy areas at delta of La Linta (south-west coast), $1-10 \mathrm{~m}$ a.s.1., 24 - 28 Aug. 1928, H. Humbert \& S. Swingle 5448 (MO, P [P04618475 \& P04618493]); Cape Sainte-Marie $\left[25.5821^{\circ} \mathrm{S}, 45.1312^{\circ} \mathrm{E}\right]$ : calcareous rocks, Cape Sainte-Marie, 1 - $100 \mathrm{~m}$ a.s.1., 5 - 7 March 1955, H. Humbert \& R. Capuron 29246 (P [P04618483]).

Localities not traced: saline areas, Tulear province, Mahofaly [specific locality not traced], no alt., 7 Oct. 1921, H. Poisson 344 [P [P04618888]); salty ground at Ampali [locality not traced], no alt., 6 July 1899, M. Douhot s.n. (P [P04618478]); saline lagoon in association with 'kisirasira', Bevato 
[locality not traced], no alt, 16 March 1967 - 1969, B. Koechlin (P [P05047811]); 'Madagascar' [no locality indicated], no alt., no date, H. Perrier de la Bâthie 13822 (P [P04618477]).

\section{Habitats}

Coral rocks, limestone rocks, sandy and saline areas near the sea shore or along saline lagoons, $0-$ 10 (- 100?) $\mathrm{m}$ a.s.l.; plants may be inundated and the branches partly floating by high tide. From our field observations and specimen label data, the substrate may be quite variable, but always calcareous and saline. At Vilankulo in Mozambique, where the plant was studied in detail, the substrate was coral rocks, in which the plants were deeply rooted in cracks and able to withstand the movements of tide and waves. In other coastal locations, for example at Tulear in Madagascar, the substrate has been indicated as limestone rocks. In Madagascar and in the central lagoon of Île Europa, the plants can also grow where calcareous sand forms a stable substrate (the plant was not seen in southern Mozambique on shores with shifting sand). At the coast near Morondava the stems of the plant were lying on salty sand with Arthrocnemum polystachyum, another salt-tolerant species of Chenopodiaceae. At Lac Tsimanampestsotsa in Madagascar, plants were growing on calcareous sand at the lake shore and on dunes slightly further away from the water. Loewen et al. (2001) have described Lac Tsimanampestsotsa as a closed carbonate evaporite basin, defined by cliffs of Eocene marine limestone to the east and a wide strip of alluvium, capping low outcrops of limestone towards the sea in the west. Altitudinal gradients within the lake basin are extremely low, and in response to seasonal changes in precipitation, the area covered by water changes dramatically in extent. These fluctuations create broad hypersaline mudflats, on which Caroxylon littoralis grows. 


\begin{abstract}
Phenology
From observations in the field (SH) made from August 2015 to January 2016 we conclude that the species flowers all year round, which agrees with the rather limited effect of seasonal change on the sea-shore habitat of the plant. No ripe fruits had been seen by any of the scholars that previously have studied material from Madagascar (Moquin-Tandon 1849; Cavaco 1954; Botschantzev 1972), and SH saw only one plant with ripening fruits in Oct. 2015.
\end{abstract}

\title{
Conservation Status
}

Using the distributional data for Fig. 2 and calculated with GeoCAT (Bachman et al. 2011) the Extent of occurrence (EOO) is $334,579 \mathrm{~km}^{2}$; this is far above the threshold for any of the IUCN Red List threatened categories (IUCN 2012). It may be noted that the Mozambique Channel makes up most of this area, with a subpopulation on one tiny island. The corresponding Area of occupancy (AOO), with a cell width of $2 \mathrm{~km}$ as recommended by IUCN (2012), is $48 \mathrm{~km}^{2}$; this is below the threshold for Endangered (EN).

With our identification of the subpopulations on the coast of Mozambique as Caroxylon littoralis, there are now more than 25 collections of this species. From the specimen label data we estimate that these signify only 9 subpopulations.

All protected areas within the range of distribution of the species are Ramsar sites. With two exceptions, the Ramsar sites protect areas of open water, not the coast itself: one site protects the entire Ile d'Europa and the surrounding waters, another site protects the shores and open water of the saline inland lake, Lac Tsimanampetsotsa, in Madagascar (data from www.protectedplanet.net). Outside these two Ramsar sites, most habitats of $C$. littoralis may be potentially threatened because of rapid construction of new coastal roads and development of new tourist resorts, lodges and hotels, facilities for "big game" fishing and other kinds of water sports. 
This is particularly the case near the few potential areas with coral rocks in southern Mozambique, but also on the coast of south-western Madagascar (according to what we can see from satellite images on Google Earth).

Because of an AOO below the threshold for EN and the limited number of locations we considered a conservation assessment of Vulnerable (VU) according to the IUCB criteria B2a, but the situation meets only one of two necessary sub-criteria for an IUCN Red List threatened category: we have neither observed continuing decline in EOO, AOO, the number of locations or the number of mature individuals (B2b), nor have we observed extreme fluctuation in any of these (B2c). We suspect that outside the protected areas on Ile d'Europa and at Lac Tsimanampetsotsa there may be threat in the future, but currently we must assess the conservation status as Least Concern (LC) to Near Threatened (LC-NT) (IUCN 2016, p. 20), pending further study of the populations and development of tourist facilities along the coasts of Mozambique and Madagascar. 


\section{Acknowledgements}

We thank Michael G. Gilbert, Royal Botanic Gardens, Kew, for his suggestions and discussions with Ib Friis whilst we tried to identify the plants from Mozambique. M.G. Gilbert and Ib Friis worked together in the 1990s on the accounts of the Chenopodiaceae for the Flora of Ethiopia and Eritrea and Flora of Somalia. We also thank Odile Weber, formerly at the Royal Botanic Gardens, Kew, now at the Inst. Biblique Belge, and an anonymous reviewer for comments on our conservation assessment.

\section{Disclosure statement}

No potential conflict of interest has been reported by the authors. 


\section{References}

Akhani H, Edwards G, Roalson EH. 2007. Diversification of the Old World Salsoleae s.1.

(Chenopodiaceae): Molecular Phylogenetic Analysis of Nuclear and Chloroplast Data Sets and a Revised Classification. International Journal of Plant Sciences 168(6): 931 - 956.

Bachman S, Moat J, Hill A, de la Torre J, Scott B. 2011. Supporting Red List threat assessments with GeoCAT: geospatial conservation assessment tool. ZooKeys 150: 117 - 126. DOI: 10. 3897/zookeys.150.2109. The software used in this study was an updated version available at http://geocat.kew.org/; accessed May 2015.

Botschantzev V. 1969. The genus Salsola L.: A short history of its development and distribution. Bot. Zhourn. 54(7): 989 - 1001. [In Russian].

Botschantzev V. 1972. Species subsectionis Tetragonae (Ulbrich) Botsch. sectionis Caroxylon (Thunb.) Fenzl generis Salsola L. Novosti Sistematiki Vyssich Rastenij [Novitates Systematicae Plantarum Vascularium] 9: 140-154. [In Russian].

Botschantzev V. 1974. A synopsis of Salsola (Chenopodiaceae) from South and South-West Africa. Kew Bulletin 29(3): 597-614.

Botschantzev V. 1978. New species of the genus Salsola L. from South and South-West Africa, IV. Bot. Zhourn. 63(6): 832 - 836. [In Russian].

Botschantzev V. 1981. New species of the genus Salsola L. from South and South-West Africa, V. Bot. Zhourn. 66(7): 1036 - 1040. [In Russian].

Botschantzev V. 1983. New species of the genus Salsola L. from South and South-West Africa, V. Bot. Zhourn. 68(9): 1247 - 1249. [In Russian]. 
Brenan JPM. 1988. [Family] 133. Chenopodiaceae. Pp. 133 - 161 in: E. Launert (ed.), Flora Zambesiaca, Vol. 9(1). Flora Zambesiaca Managing Committee, London.

Cavaco A. 1954. 66 ${ }^{\mathrm{e}}$ Fam. Chenopodiaceae. In: H. Humbert (ed.), Flore de Madagascar et des Comores. Fasc. 66 (Chenopodiacées), 67 (Amaranthacées), 68 (Nyctaginacées), 69

(Phytolaccacées). Firmin-Didot, Paris. Pp. 1 - 15.

Google Earth. 2016. Google Earth, vers. 7.1.5.1557. [On line]. https://www.google.com/earth/ (accessed 14 Aug., 2016).

IDC. 1962. Prodromi herbarium, herbarium genevense. Photographs of the plant specimens used for

De Candolle's Prodromus systematis naturalis regni vegetabilis (17 v.) in the herbarium (Herbier De Candolle) at the Botanical Conservatory of Geneva. IDC 800: 2842 fiches (17 v.) in 83 boxes.

IUCN. 2012. IUCN Red List Categories and Criteria. Version 3.1. Second edition. Gland \& Cambridge.

IUCN. 2016. IUCN Standards and Petitions Subcommittee. Guidelines for Using the IUCN Red List Categories and Criteria. Version 12 (February 2016). http://www.iucnredlist.org/documents /RedListGuidelines.pdf; accessed 30 September 2016.

Loewen, MA, Samonds, KE, Ramarolahy, MF. 2001. Lake Tsimanampetsotsa, A Modern Alkaline Playa Lake in Madagascar. Paper No. 182-0.

https://gsa.confex.com/gsa/2001AM/finalprogram/abstract_26774.htm; accesses 30 September, 2016.

Moquin-Tandon CHBA. 1849. Salsolaceae. In: A. De Candolle (ed.), Prodromus systematis Naturalis Regnae Vegetabilis. Vol. 13(2). Victor Masson, Paris. Pp. 87 - 219. 


\section{Legends to Figs}

Fig. 1. Caroxylon littoralis. (A) Plant exposed to full sun on dry coral rock under low-tide. (Photo F7860. 9 Sep., 2015). (B) Plant floating and immersed during high-tide. (Photo F8455 13 Nov., 2015). (C) Scanned, freshly collected specimen. (D) Detail of the partly lignified stem and the herbaceous branches. (Photo no. F7859. 9 Sep., 2015). (E) End of branch, showing long hairs emerging from young leaves. (Photo no. F8472. 13 Nov., 2015). (F) Open flower with bracts and bracteoles, protruding membranous perianth segments, style and stigma. (Photo No. F7959. 6 Oct., 2015). (G) Longitudinal section of flowering branch, showing bracts, membranous perianth segments and part of stamens. (Photo no. F7997. 7 Oct., 2015). (H) Longitudinal section of flower, bracts, perianth segments and pistil. (Photo no. F8879. 22 Jan., 2016). (J) Opened flower, showing perianth segments, stamens and pistil. (Photo no. F8868; 22 Jan., 2016). (K) Achenes. (Photo no. F7981. 7 Oct., 2015).

Fig. 2. Caroxylon littoralis: Map of the distribution, based on the data cited in this paper. 

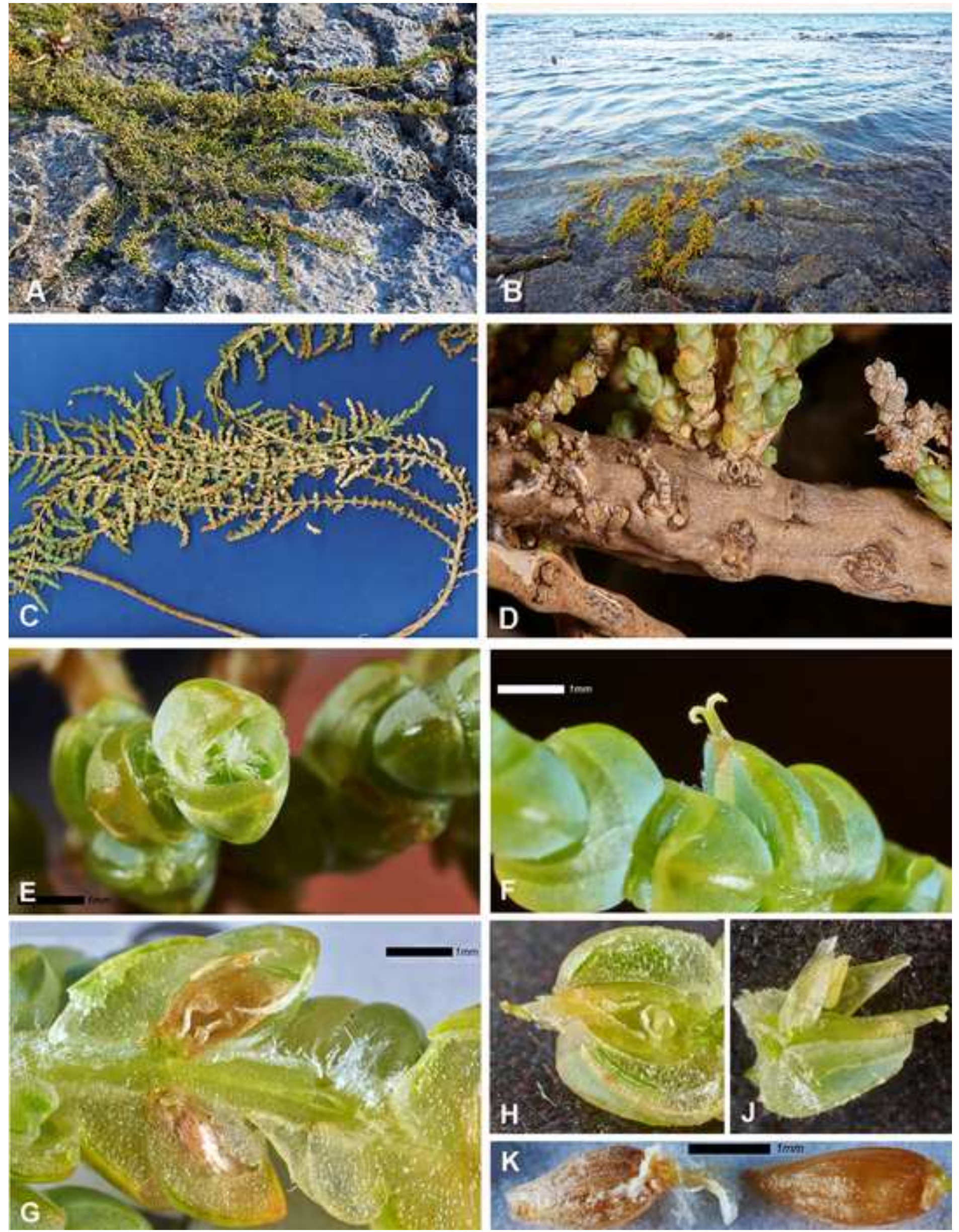

forsin 

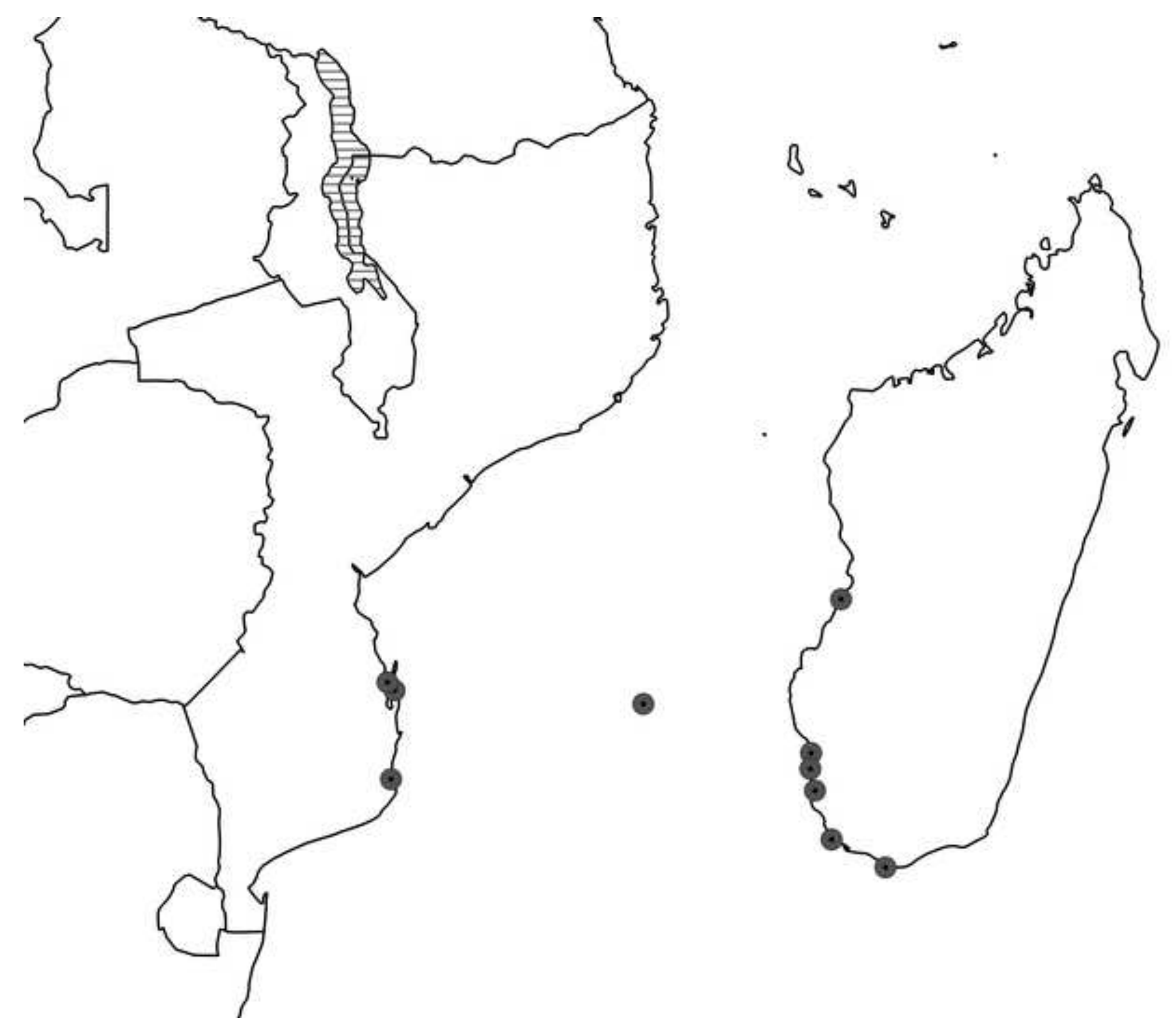